\title{
The role of school culture in the formation of student character in SMPN 4 Kaubun Kabupaten Kutai Timur
}

\author{
Johansyah \\ Faculty of Teacher Training and Education, Mulawarman University, Samarinda, East Kalimantan, Indonesia \\ syamjohansyah@gmail.com
}

\begin{abstract}
This study aims to determine the role of school culture applied in SMPN 4 Kaubun, the success of school culture to build the character of students, and the supporting and inhibiting factors in the implementation of school culture. The study focuses on three school cultures, which are religious, discipline, and reading interests. This study was conducted qualitatively to describe the information from informants in SMPN 4 Kaubun comprehensively, holistically, integrative, and deeply. Data collection was done by observation, interviews, and documentation used as supporting data in analyzing the character of students. The subjects of this study consisted of the headmaster as key informant, and teachers as supporting informants. The process of data analysis was conducted through several stages, which are data collection, data reduction, data presentation and verification or conclusion. Descriptive analysis was used to analyze data critically and synthetically. The results of this study show that there were several habituation activities applied in the school, including religious culture, discipline, and reading interest which have an important role in the student character building. The supporting factors in the implementation of school culture were the togetherness and kinship among school members and the participation of stakeholders in its implementation. While the inhibiting factors were weather conditions, poor road access, environment, and family that background student character.
\end{abstract}

Keywords - school culture, stakeholder, character

\section{INTRODUCTION}

Education, in essence, is an effort to develop student social personality [1]. Education is an attempt to shape the human character for the better. Furthermore, the Law of National Education System of Indonesia, mentioned that education is a conscious and planned effort to create learning atmosphere and process to get students active and be able to develop their own potential in order to have religion spiritual power, self-control, personality, intelligence, noble character and also skill which useful for his or her life, society, and nation[2].

On the other hand, school is an institution of the learning process or can be said as an agent of change for society[3]. Therefore, school management should be conducted appropriately. Because of this notion, the school provides a complex and dynamic system in its activities and should be well managed in order to produce quality output in accordance with the demands of community needs[4]. School culture is a set of values that underlie the behavior, traditions, daily habits, and symbols practiced by principals, teachers, administrative staff, learners and the community around the school. School culture has certain characteristics. The school culture should have a clear mission in creating a challenging and fair, creative, innovative, integrative, and creative school culture toward the achievement of vision, producing highly qualified graduates in intellectual development.

School culture is a pattern of values, principles, traditions, and habits formed in the long journey of schools, developed the school in the long term and become a grip and is believed by all the citizens of the school that encourages the emergence of attitude and behavior of the school[5].

\section{METHOD}

\section{A. Type of Study}

This study is descriptive qualitative that is fact-finding with proper interpretation. Others argue that a qualitative approach seeks to describe comprehensively, holistically, integrative, and deeply through observing people in their environment and interacting with them about the world around them. Thus, researchers try to enter in the object of study so that they can get data accurately[6].

\section{B. Background Study}

The study was conducted at SMPN 4 Kaubun of East Kutai District with the sample was done purposively. A qualitative study has no random sample, but there is only purposive sampling.

\section{Data Collection and Recording Procedures}

To obtain the necessary data in this study, there are two data that must be studied, that is the data of teacher role in building culture and character. In addition, these two data use several methods of this study.

To obtain cultural data, it is used several methods, which were observation, interview, and documentation. In interview method, some results are expected to reveal the following questions:

- What is the role of school culture to shape the character of students in SMP N 4 Kaubun East Kutai District? 
- How is the success of school culture to shape the character of students in SMPN 4 Kaubun East Kutai District?

- What are the factors that support and inhibit the school culture to shape the character of students in SMPN 4 Kaubun East Kutai District?

In the other hand, to obtain character data, it was used a questionnaire filled by some principal informants and teachers who are considered to have been a longer teaching staff at the school.

\section{Data Analysis Technique}

Data analysis consisted of data collection, data reduction, triangulation and presentation of data. The validity of the data is an important factor in this study. Some criteria were used to improve or know the validity of data, which were degree of trust, transferability, dependence, and certainty[7].

\section{DISCUSSION}

\section{A. The Role of School Culture in the Building of Student Character in SMPN 4 Kaubun.}

Based on the observation, the teachers always invite Islamic students to pray in school mosque. Principals, teachers, and students at SMPN 4 Kaubun pray together before carrying out the learning activities, which are done every morning. This activity is also an implementation of religious culture that can be implanted to all students that prayer is part of the effort to be done by students and is a powerful weapon for the success of life and the hereafter.

In addition, from the interview result, the principal plays an important role in shaping the school culture in the building of student character, where the principal is a model and inspiration for the school's citizens behave. While the teacher as the second informant revealed that the role of school culture in the character building of students in SMPN 4 Kaubun East Kutai District. This is as revealed in the following interview results:

Moreover, teachers are the spearhead in the classroom that is directly opposite the students. Therefore, the teacher must understand and apply the character education indicator first to his or her own personality. Basically, in character education, the role of teachers has a compound function, as a teacher, educator, model and so forth[8]. However, ideally, a teacher is expected to play a role model and inspiration for the child in behave. That the role of school culture in the building of student character cannot be separated from the cooperation between teachers, principals and school committees as stakeholders applied at school and in society later. In the building of student character, the teacher is a vital role, therefore, the teacher should be a model for students, especially the interaction among students.

Based on the results of interviews with the four informants, they have the same opinion and also there are few differences among them. The same opinion from the informants GR1, GR2, GR3, and KS is the role of school culture in the building of student character done by teachers and principals of the very large positive impact that is manifested with religious culture, discipline, and likes to read. While the difference is from informant 2 states that not only principals and teachers who play but school committee as stakeholders also contribute to the realization of school culture in SMPN 4 Kaubun.

Based on interviews, observations and documentation, his findings that school culture as "the pattern of values, norms, attitudes, myths and habits formed in the long journey of a school, where the school is held together by the principal, teachers, staff, as well as students, as their basis for understanding and solving problems that arise in school. In other words that culture or school culture can be said as the thoughts, words, attitudes, deeds, and hearts of every citizen of the school which is reflected in the spirit, behavior and symbols and their distinctive identity slogan. And listening from the definition above can be understood that the concept of school culture as an approach more emphasis on appreciation of the symbolic aspects, tradition, history of schools, that is all will form the confidence and pride of the school.

A good school culture will effectively produce the best performance in each individual, workgroup/unit and school as an institution, and a synergic relationship between the three levels[5]. School culture is expected to improve school quality, school performance and the quality of life expected to have healthy, dynamic or active, positive and professional characteristics. The culture of a healthy school provides opportunities for schools and school residents to function optimally, to work efficiently, energetically, full of vitality, have high spirits, and will be able to continue to grow.

Meanwhile, the data obtained from the three teacher informants related to several school cultures applied in SMPN 4 Kaubun are as follows:

\section{1) Religious Culture}

In the religious culture revealed the results of the interview as follows: teacher is followed and imitated, is a phrase that symbolizes how the position of the teacher will always be a concern for students, parents or society and can be applied through religious culture that is by doing mutual prayer together, the implementation of dhuha prayers and prayers dhuhur together.

That the role of school culture in the formation of student character cannot be separated from the cooperation between teachers, principals and school committee as stakeholders applied both in school and in society later, for example in religious culture, namely the implementation of dhuha prayer and dhuhur praying in congregation and PHBI activities such as studies in the context of isra 'mi'raj, Maulid Nabi, Pesantren Ramadhan, Halal bi halal and warnings for other non-Islamic religions conducted in schools.

Teachers are vital role holders, therefore, teachers should be role models or models for learners, especially students who directly interact with students, of course, should be more proactive in all student activities. For example, in religious culture, which is the implementation of dhuha prayer and dhuhur prayer congregation for the Muslims and prayer together for students who believe other religions.

Based on the results of interviews with the three informants, they have the same opinion and also there are few 
differences between the teacher council and the students who pray together before carrying out the learning activities, as well as dhuha and dhuhur prayer in school mosques for Muslims, according to the second teacher informant revealed that at certain moments, such as PHBI activities, for example study in the context of isra 'mi'raj, Maulid Nabi, Ramadhan activities, Halal bi halal and celebrate for other religions held in schools.

\section{2) Culture of Disciplines}

The results revealed that culture of discipline is defined implementing mutually agreed rules. In the implementation of a disciplined culture, for example, on time in all activities, the use of uniforms according to the rules, and obeying the rule that has been agreed through meetings with the parents of the students each year. Cultural discipline, with the rules that must be obeyed by the students, it is expected to create a conducive situation by providing rewards for those who comply with regulations and punishment for those who violate the rules[9].

Based on the results of interviews with the three informants, most of them have the same opinion and also there are few differences, there are other big day ceremonies, such as the commemoration ceremony of independence, Kartini's day, national education day and others. Not only in the flag ceremony, the discipline culture also can be realized with the application of school rules, the correct use of school uniforms and complete attributes, discipline on time of entry and return from school, and does not violate the rules set by the school.

Moreover, from the three informants, they have the same opinion and also there are few differences, in accordance with the opinion of experts who stated that discipline in school is important in supporting the success of the rules that are applied in schools, in which teachers and students are joined to the rules that have been applied. The discipline applied aims to improve the quality of children's learning in Teaching and Learning Activities. The goal is for the development of selfcontrol, in which children can self-directed without outside influence and control. Therefore, parents must actively and continuously strive, to play the smaller role of the disciplinary work, by gradually developing self-control and direction on the children.

\section{3) Reading Interest}

In the culture of Reading, it is revealed the results of the interview that school culture is expected to form the character of students who are religious, disciplined, and insightful. The culture of reading interest, that is implementing literacy program of school which is held 15 minutes before the process of Teaching and Learning Activities is carried out in turn. This culture is achieved with school literacy program by visiting the library every day before start learning.

School literacy is a comprehensive and continuous effort to make the school as a long life literary organization, this activity is carried out every day in turn between classes aimed at 1) Growing the literacy culture of reading and writing students in schools, 2) Increasing the capacity of citizens and a literate school environment, 3) Make school as a fun and child-friendly learning park so that schoolchildren can manage knowledge, 4) Maintain sustainability and learning by presenting a variety of reading books that embrace various reading strategies[10]. This movement is the embodiment of the reading culture in SMPN 4 Kaubun.

\section{B. The success of school culture to shape the character of students in SMPN 4 Kaubun.}

From the interviews of the four informants, it can be concluded that the role of school culture in the building of student character by teachers, principals is very important and strategic[5]. As a principal who must be responsible for the management or school management, the success in building a school culture is good although still not maximal because there are still many obstacles encountered, including still a good offense committed by unscrupulous teachers or students, who overcome, by the principal and the board of teachers always interact and synergize in overcoming the problem.

The success in building the school culture is very satisfactory because in addition to implementing a school culture that aims to students was also affected teachers and staff at SMPN 4 Kaubun to always get used to implementing the school culture, where the teacher is a followed and imitated figures or a good model. In terms of the success of school culture applied in the school, it has increased significantly, because students are more proactive in awareness and improvement of faith and taqwa which is the embodiment of religious culture, a sense of responsibility that is the implementation of discipline culture, students are more interested in reading that automatically will increase the insight is a form of reading culture.

Success in building a school culture to shape the character of students, in my opinion is more than enough or in other words, has almost reached the expected target of school goals. Based on the results of interviews with the four informants, they have the same opinion about the success in building school culture to shape the character of students in SMPN 4 Kaubun, but there is little difference with the opinion of the principal. The same opinion from informants GR1, GR2, and GR3, that is the school culture that has been applied has a positive impact on the character development of students in SMPN 4 Kaubun. The school culture makes the school as a comfortable place to learn and safe to interact because it is supported by a conducive environment under the supervision of the principal, the board of teachers and staff at the school, it is also the hope of parents who have entrusted their children to study at SMPN 4 Kaubun. It is intended that each action contains an element of responsibility on each individual.

Based on the results of interviews with the three informants, they have the same opinion and also there are few differences. It stated that the first teacher only declared the purpose of reading and the second teacher stated the implementation of the program reading or school literacy is practiced in 15 minutes before learning activities begin in turns with the same opinion as for the third teacher. This activity is carried out every day in order to develop literacy culture of reading and writing of students in schools, increase the capacity of citizens and the literary school environment, make school as a learning park that enjoyable and child friendly so that the school people can manage the knowledge, maintain 
sustainability and learning by presenting a variety of reading books that accommodate various strategies of reading.

In line with the opinion of the Government through the Regulation of Education and Culture Minister No. 23 of 2015, it has realized the importance of the character growth of students through reading policy for 15 minutes before the lesson begins. But, this great plan cannot be succeeded instantly and temporarily. That will be built is a habit, then it takes a habituation that must be continuously done from an early age and for that consistency is needed.

Literacy activity is identical with reading and writing activities. However, the Praha Declaration in 2003 mentioned that literacy also includes how one communicates within a society. Literacy also means practices and social relationships related to knowledge, language, and culture (UNESCO, 2003). In addition to the role of the principal as an innovator in order to form the character of the students, the role of the teacher also cannot we ignore, because the teacher is the part of the government that shapes the character of the students, especially during the process of education in school. Then the parents, as well as members of the community have more time in fostering the character of their children.

The application of punishment for students who violate the rules and rewards for students who run the order is also applied, it is intended that each action contains elements of responsibility in each individual.

In line with the opinion that the character building of students in school is success if students and teachers come from the same local culture. Teachers who know more in the local culture of their students will be more fluent and more successful in forming the character of their students compared with teachers who are less familiar with or lack understanding of the local culture of their students. It is a big task and challenge for teachers assigned to culturally diverse cultures

\section{Inhibiting and supporting factors in the implementation of school culture in SMPN 4 Kaubun.}

There are some inhibiting factors of school culture implementation. First, the factor of weather conditions, if the rainy season arrives then the culture of discipline and religious often cannot be accomplished according to the scheduled agenda. Second, there are differences in environmental and family factors, so teachers find some obstacles in handling students. While the factors supporting the implementation of school culture according to the four informants is the same, that is the existence of togetherness between the school community and stakeholders in building a school culture for the character building of students in SMPN 4 Kaubun.

Interviews were conducted on four informants, principals as a main information source (KS), and 3 teachers, (GR1), (GR2), and (GR3). The informants have the same argument about what factors are supporting and inhibiting in building a school culture to shape the character of students in SMPN 4 Kaubun. The supporting factor is the togetherness and awareness that is done by all school residents about the importance of school culture which gradually brings positive impact for all school residents especially students. The inhibiting factors in building a school culture are weather, because if it is raining, then prayer together program often cannot be conducted because many students are delayed due to poor access roads to the school.

Based on the results of interviews, observations, and documentation, it has been found that the factors supporting the implementation of school culture according to the four informants are togetherness and kinship among the citizens of the school and this becomes something very important in building a conducive and comfortable school culture. Moreover, the participation of stakeholders, such as school committee, parents, and residents around the school environment as well as the government and companies located near the school, in building a school culture for character building students in SMPN 4 Kaubun. This is in accordance with document 1 on the mission of the school is to grow a sense of kinship among fellow citizens of SMP Negeri 4 Kaubun.

In line with the opinion that the development of a conducive school culture for character development is conducted integrated with all school activities, from learning, extracurricular, school infrastructure, school financial management, school relationships with parents and the community, and others. That is, all aspects of the school are designed and directed to be conducive to the seeding and development of student character.

While the inhibiting factors faced by teachers and principals in applying school culture to the character building of students are the weather conditions because if the rainy season arrives then the culture of discipline, religious culture and environmental caring culture often cannot be accomplished in accordance with the scheduled agenda. Moreover, poor road access also contributes to inhibiting the implementation of school culture. The road material consists of rock and soil, even in the dry season, damaged roads become the inhibiting factor in the implementation of school culture. Then, the differences in student character, environmental and family background can be the obstacles for teacher in handling students.

The development of a conducive school culture to developing a positive character of the student is done by observing the following principles, which are sustainable, integrated, consistent, implementative, and fun [11].

\section{CONCLUSION}

The role of school culture in shaping of student character in SMPN 4 Kaubun is very important and strategic, and the result is highly dependent on the professionalism of teachers in implementing the program and the teacher's personality through exemplary in every activity that students can observe where the teacher's role is very important for the success of character education. The principal's participation in managing academic and non-academic conditions, as well as the ability to create a conducive school atmosphere. Then, the success of teachers in building a school culture to shape the character of students in SMPN 4 Kaubun, in general, is quite significant or good. The school culture that has been implemented has a positive impact on the character development of students in 
SMPN 4 Kaubun. Furthermore, factors supporting the implementation of school culture according to the four informants are togetherness and kinship between school residents and the participation of stakeholders such as school committees, parents, and residents around the school environment as well as local governments and companies located near the school. In the other hand, inhibiting factors faced by teachers and principals in applying school culture to character building of students: weather conditions, poor road access and differences in student character and environmental, and also family factors that underlie student character.

\section{REFERENCES}

[1] G. Gay, At the Essence of Learning: Multicultural Education. 1993.

[2] Z. Baidhawy, "BUILDING HARMONY AND PEACE THROUGH MULTICULTURALIST THEOLOGY-BASED RELIGIOUS EDUCATION: An Alternative for Contemporary Indonesia," Br. J. Relig. Educ., vol. 29, no. 1, pp. 1-18, 2007.
[3] J. I. Goodlad, A place called school. Prospects for the future. New York: McGraw-Hill Book Company, 1984.

[4] G. Everard, K. \& Morris, Effective School Management. 1996.

[5] A. J. MacNeil, D. L. Prater, and S. Busch, "The effects of school culture and climate on student achievement.," Int. J. Leadersh. Educ., vol. 12, no. 1, pp. 73-84, 2009.

[6] R. Bogdan and S. Biklen, Qualitative research for education: An introduction to theory and practice. Boston: Allyn and Bacon, 2007.

[7] C. S. Jacelon and K. K. O'Dell, Analyzing qualitative data., vol. 25, no. 3. 2005.

[8] F. Musgrove and P. H. Taylor, Society and the Teacher's Role (RLE Edu N). Routledge, 2012.

[9] D. Osher, G. G. Bear, J. R. Sprague, and W. Doyle, "How Can We Improve School Discipline?," Educ. Res., vol. 39, no. 1, pp. 48-58, 2010.

[10] A. Purves and R. Beach, "Literature and the Reader: Research in Response to Literature, Reading Interests, and the Teaching of Literature," English J., vol. 63, no. 3, p. 113, 1972.

[11] A. N. Stricker, "Learning Leadership: An Investigation of Principals' Attitudes Toward Teachers in Creating the Conditions Conducive for Learning in School-based Staff Development," ProQuest LLC., p. pp 227-232, 2006. 